\title{
THE RECENT DEVELOPMENT TRENDS IN MANAGEMENT OF AGRICULTURAL HOLDINGS
}

\author{
Zuzana Juríčková ${ }^{1}$, Zuzana Kapsdorferová ${ }^{1}$, Mária Kadlečíková ${ }^{1}$ \\ ${ }^{1}$ Department of Management, Faculty of Economics and Management, Slovak University of Agriculture, \\ Tr. A. Hlinku 2, Nitra, Slovakia
}

To cite this article: JURÍČKOVÁ ZUZANA, KAPSDORFEROVÁ ZUZANA, KADLEČÍKOVÁ MÁRIA. 2018. The Recent Development Trends in Management of Agricultural Holdings. Acta Universitatis Agriculturae et Silviculturae Mendelianae Brunensis, 66(6): 1509-1516.

To link to this article: https://doi.org/10.11118/actaun201866061509

\begin{abstract}
The aim of this scientific paper is to present recent development trends in the management of agricultural holdings in the Slovak Republic. Furthermore, the objective is to identify new trends in managerial competencies, the factors that represent key conditions for the business success of agricultural holdings, respectively the obstacles to increased competitiveness, and identify new trends in the utilization of progressive methods, techniques, tools and approaches to management. Several research hypotheses and scientific assumptions were set related to the purpose of the scientific contribution. Mathematical and statistical methods were applied for the statistical testing of the hypothesis - nonparametric tests. The results of a questionnaire survey were used as a source of data and this involved 96 top managers employed in agricultural holdings in the Slovak Republic. Stemming up from the results of our survey, managers among the others tools apply outsourcing (46, 88\%), diversification (92,71\%) and information technologies (56, 99\%). The results confirm that although managerial approaches and methods have changed significantly as a result of multiple socio-political and economic transformations, managers need to pay greater attention to environmental aspects, to transfer of innovations and to project management and knowledge management.
\end{abstract}

Keywords: agricultural holding, manager, managerial functions, management tools, management methods, managerial approaches

\section{INTRODUCTION}

Numerous organizational changes are spreading through essential structural interventions in agriculture and rural development. These changes relate to the transition of a centrally planned system to a market economy, to EU accession, to growing pressure on the agricultural commodities market, volatile price development, the ageing of people employed in the agribusiness sector, to limited resources, and to free movement on European markets. The most decisive factor influencing agricultural policy was the accession of the Slovak Republic to the European Union in 2004. It was necessary to adhere to the tools of Common Agricultural Policies (CAP), which are diametrically different from the tools utilized in the pre-accession period.

Serenčéš and Tóth (2012), state that a decisive role is played by managers, who are leading agricultural companies. To a great extent it will depend upon them how they will be able to adapt themselves to these dynamic changes and actively introduce them into agricultural practice. Kádárová and Durkáčová (2012), as well as Karabašová (2010), analysed the use of managerial tools in the process of enterprise performance growth. The conclusion 
is that the principal applied methods and tools in the domestic and global framework are the following factors: knowledge management, strategic management, planning, alternatives, crisis management, formulation of missions and visions, orientation on key competencies, change management, consumer relations management and others.

Another progressive managerial tool is represented by production diversification. Tóthová and Fil'a (2014) did a survey in Slovakia. According of their results more than $90 \%$ of agricultural holdings are applying this approach, since the Slovak managers consider it as strong and powerful driving force for development of agriculture and countryside, especially in the field of increasing competitiveness and financial health of companies.

Among the influential managerial tools in the agri-food sector belongs also establishment of inputs and outputs cooperatives/associations. Sedik (2016), claims that in Hungary 3\% of agricultural holdings are involved in this kind of cooperation, while in Ukraine only $0,4 \%$. On the other side in Italy this indicator achieves $54 \%$ and in the USA even $100 \%$.

Dobošová et al. (2017), are highlighting the importance of controlling. They state that controlling is the managerial tool in agricultural business and it is important part of the business management system. According of these authors this tool will allow to recognize not only the effects of economic and non-economic factors, but also to identify their further developments in order to analyze the deviations from the regular trend and find out the ways for their mitigations.

Yar (2017), claims that future development of agriculture and food production depends on new technologies and innovative approaches. The latest innovation employed by farmers is based on smartphone applications.

Takácsné et al. (2018), claim that from modern technologies in agriculture the important role plays precision agriculture which leads to the increasing yields and higher profitability benefits. However, the high investment cost is the main barrier to diffusion, while subsidies, as well as more appropriate information can foster it.

Roos and O 'Connor (2015) state that technological innovations are a driving force in permanently changing the economic world. Fresco (2015), in relation to agricultural innovation, claims that important innovations are expected in the field of genetics, ICT, bio-economics or in optimization of the food chain. With social and economic development are coming changes which force enterprises to adjust themselves to newly created situations.

The objective of the submitted article is the evaluation of recent state of management in agricultural holdings of the Slovak Republic, as well as the identification of trends in managerial competencies, definition of those factors which according of agro-managers represent key conditions for success, resp. The obstacles on their way to higher competitiveness.

\section{MATERIALS AND METHODS}

In order to have the opportunity to compare the conditions, levels and results of the agricultural entities in the different stages of their development, quantitative data has been selected and processed from the Green Reports covering the years 2001 to 2016 (Ministry of Agriculture and Rural Development - MARD, 2001-2017). The questionnaire survey was undertaken in order to obtain primary information and qualitative data. Before conducting the questionnaire survey itself, a pilot survey was carried out to verify the clarity of the questionnaire. The pilot survey in 2015 preceded the main research, which continued until 2017. The questionnaire was composed from 44 questions, of which 6 were open, 7 semi-closed and 31 closed - alternative questions. In this connection, 96 managers of agricultural holdings were addressed. The questionnaire was distributed electronically through Google Forms. The MS EXCEL 2016 programme was used with a table processor for primary data processing, organization, adjustment and preparation of graphical outputs and tables. Mathematical and statistical methods were used to evaluate the research hypotheses. The research is based on five hypotheses.

\section{Hypothesis no.1}

The introduction of new development trends in management has positive impact on the prosperity of agricultural holdings.Friedman test

\section{Hypothesis no.2}

The changes in the external environment have, according to managers significant impact on the successful operation of agricultural holdings. Friedman test

\section{Hypothesis no.3}

Organizational structure and its impact on production and economic results. Kruskal-Wallis test

\section{Hypothesis no. 4}

Management pay equal to the importance of management functions. Friedman test

\section{Hypothesis no. 5}

EU accession had an essential impact on the nature of agribusiness managers` work. Kruskal-Wallis test

\section{RESULTS}

After transition process and EU accession, the agricultural sector is marked by a sharp decline in its economic significance, the share of agricultural production on GDP has lowered from 3, 
$60 \%$ in 2001 to $2,40 \%$ in 2016 (MARD, 2001-2017). The foreign trade deficit of agricultural commodities is growing $(6,3 \%$ in 2017, MARD, 2017) and there is a marked decline in agricultural employment from $5,24 \%$ to $2,89 \%$ (MARD, 2001-2017). The overall agricultural production dropped about $2 \%$ with dramatic development in animal production. In this sector the production declined about 19,1\%, while crop production noted significant increase about 16,1\% (MARD). Over the above indicated period the sector's importance has been seriously affected and the sector is no longer considered a priority area. Only new technologies and progressive managerial tools can lead to effective agricultural production under Slovak conditions. This refers also to the high absorption capacity of EU funds, to production innovation, the contribution to food self-sufficiency, food quality improvement, and increased competitiveness.

\section{Description of the Selected Group of Agricultural Holdings}

The questionnaire survey was carried out in the 8 regions of the Slovak Republic. In the surveyed group the most dominant category were agricultural holdings which had been established during the transition process. Companies created after EU accession, respectively they are still in existence, represent a modest share of the surveyed group. The biggest share is made up of small companies (52.63\%), microenterprises and small enterprises (22.11\%, or $25.26 \%)$. 96 top managers from agricultural holdings were involved in the survey. $80.2 \%$ of managers had obtained a university education. This optimistic result documents that from an educational point of view, managers are well prepared for the prosperous encompassment of managerial functions under the recent demanding, changing conditions.

\section{New Trends of Management in Agricultural Holdings}

Management systems in agriculture are very complex processes. Managers have to face the recent challenges of ensuring food safety and quality, dealing effectively with climate change, changing agricultural policy and coping with the requirements linked to the modernization of agricultural production through the introduction of new technologies, including ICT. In this connection the main responsibility rests with managers of agricultural holdings, primarily with regard to the decisionmaking process in real time. Agricultural managers on the one hand face information asymmetry, while on the other hand they paradoxically do have at their disposal a huge amount of information, which is exponentially growing, though decisionmaking techniques are lagging behind this growth. The position of agribusiness managers is thus becoming more complex.

\section{Changes in the External Environment and its Impact on the Operation of Agricultural Holdings}

The environment, in which agricultural holdings operate, affects their position. The manager's role is to follow, evaluate, adapt and utilize changes in the external environment of agricultural holdings in their favor. With the intention of studying these issues in greater detail, the answers obtained from the survey were tested utilizing the Friedman test. The agribusinessmen of the selected firms consider economic and technological changes in their external environment of primary importance. In the second group with analogical level of p-values are listed legislative and ecological changes. Social and political changes are grouped into the third category. According to the evaluated criteria these have a lower impact on the surveyed group, however, their average level is still high in comparison with the first category. The test results (Tab. I.) demonstrate that all changes in the external environment have a substantial impact on agricultural companies.

Among the factors which represent the greatest obstacles to the work of managers are state bureaucracy (68.4\%) and the lack of a concept of agricultural and rural development (57.9\%). Almost half of the respondents consider that a most unfair practice is the low proportion of profit that primary producers earn in comparison with other actors in the food chain. A meaningful barriers are the frequent turbulent changes in the business environment (legislative, energy

I: The Results of the Friedman and Kruskal-Wallis Testings

\begin{tabular}{|c|c|c|c|c|c|}
\hline Test Statistics & $\begin{array}{c}1 . \\
\text { Friedman } \\
\text { New development } \\
\text { trends Factors } \\
\text { of enterprise' } \\
\text { prosperity }\end{array}$ & $\begin{array}{c}2 . \\
\text { Friedman } \\
\text { Estimation of } \\
\text { significance } \\
\text { of the changes } \\
\text { in external } \\
\text { environment }\end{array}$ & $\begin{array}{c}3 . \\
\text { Kruskal-Wallis } \\
\text { Organizational } \\
\text { structure and } \\
\text { its impact on } \\
\text { production and } \\
\text { economic results }\end{array}$ & $\begin{array}{c}4 . \\
\text { Friedman } \\
\text { Perception of } \\
\text { management } \\
\text { functions } \\
\text { importance }\end{array}$ & $\begin{array}{c}5 . \\
\text { Kruskal - Wallis } \\
\text { Impact of EU } \\
\text { accession on } \\
\text { managerial work }\end{array}$ \\
\hline $\mathbf{N}$ of Valid Cases & 87 & 86 & & 93 & \\
\hline Chi-Square & 132,12 & 83,002 & 0,421 & 19,037 & 2,108 \\
\hline Df & 6 & 5 & 2 & 6 & 4 \\
\hline Asymp.Sig. & 0,000 & 0,000 & 0,810 & 0,004 & 0,716 \\
\hline
\end{tabular}

Source: own research 
prices, administrative business prerequisites etc.). $31.6 \%$ of managers emphasize that there is a lack of coordination among primary producers with regard to the procurement of inputs and the sale of their products. So far, very few inputs-sale associations/cooperatives have been created, therefore negotiating power with food processors or purchasers is weak. Moreover, frequent changes in the political elite, both in the sector and in government (31.6\%) also have negative impacts on the company's growing performance.

\section{Organizational Structure and its Impact on Sustainable Development}

In the surveyed group functional organizational structure dominates (37\%), followed by branch structure with 34\%. The hybrid structure which benefits from the strength of the branch organizational structure, as well as from the functional or territorial structures, represents $26 \%$. Formerly preferred territorial organizational structure has appeared only in $3 \%$ of the agricultural holdings. Despite this, analyzed agricultural companies prefer more simple organizational structures and managers consider well-selected organizational structures as the meaningful factor for a company's sustainable development. (Tab. I).

Furthermore, it was confirmed that applied organizational structure has substantial effects on production and economic results (Tab. I). This statement was confirmed by $72.63 \%$ of managers.

\section{The Importance of Individual Managerial Functions}

In most management definitions, management itself is described as a process of systematic planning, organization, leadership and control which leads to the achievement of an organization's objectives. The above-listed activities represent management functions. Individual managers have the tendency to place greater emphasis on some of these functions depending on their capabilities and the actual business case. This can be also influenced by new development managerial trends, which put greater emphasis on one managerial function. Within the framework of the research undertaken, the importance of the individual functions for management was also explored.
The importance which is given by agribusinessmen to the individual management functions was analyzed by the Friedman test (Tab. I). The significance level is $\alpha=0.05$. As $p$ value is 0.004 , it is valid $p<\alpha$ $(0.004<0.05)$. Hypothesis $\mathrm{H}_{0}$ about the equality is rejected. With the support of the post-hoc test (Tab. I) an answer was obtained on the question regarding among which functions do differences appear related to their importance according to the manager's views. The testing resulted in the creation of three groups. The decision-making process and organization functions are considered by managers to be the most meaningful. In relation to the information boom, sometimes marked with information asymmetry, the importance given to the decision-making process is reasonable. People management (leadership) was identified by the respondents, as the third most important managerial function. The issue of employee management in agricultural holdings is becoming more and more complicated, due to a permanently declining interest in agricultural work, as well as on account of the seasonal nature of the working processes in this sector. Digitalization and mass data, information and communication technologies have impacts on the establishment of new farming systems. Farmers will face a flood of data in the form of sensors, satellites, robots and all kinds of other tools including drones. Human resources have to be prepared for this revolutionary development, at all managerial levels. Obviously in the near future we will speak less about manual working forces and more about operators. Apart from this, managers have to be prepared for a situation where they will lead people with a substantially higher educational level.

\section{The Factors of Agricultural Companies Prosperity}

The basic role of managers is primarily the effective accomplishment of the key goal in their enterprise, which is obviously prosperity. The effectiveness of a manager's work is influenced by numerous factors, methods and tools which are applied at the realization of managerial tasks.

The prosperity factor's importance was tested by the Friedman test (Tab. I.). The following factors have been taken into consideration: vision and strategies, analysis of the business environment, product

II: The Prosperity Factors of the Agricultural Holdings

\begin{tabular}{lccc}
\hline \multicolumn{1}{c}{ Factors/Importance in $\%$} & Very important & Important & Not important \\
\hline Vision and strategy & 62.1 & 34.7 & 3.2 \\
\hline Analysis of business environment & 53.2 & 42.6 & 4.3 \\
Product quality & 80.2 & 19.8 & 0 \\
Cost decrease & 55.3 & 43.6 & 1.1 \\
Marketing development & 46.8 & 46.8 & 6.4 \\
ICT use & 38.9 & 56.8 & 4.2 \\
Benchmarking & 14.1 & 52.2 & 33.7 \\
\hline
\end{tabular}

Source: Own research 
quality, cost decrease, marketing development, ICT utilization and benchmarking.

Whereas, the $p$ value (Asymp. Sig) is 0.000 , it is valid $\mathrm{p}<\alpha(0.000<0.05)$, therefore the hypothesis HO is rejected. "The selected enterprise's prosperity factors consider respondents as equally important".

From the Post-hoc testing undertaken by Wilcoxon a test for individual enterprise prosperity factor combinations, we learned between which factors there exists a difference and the importance of this difference.

The emphasis given to product quality and effective cost utilization are listed in the first group. For agricultural entities this represents an important trend towards more effective production and economic results. Meaningful is also the result related to the factor - vision and strategy. The lowest evaluation was assigned to the utilization of ICT. This result confirms that agribusinessmen are not taking advantage of all the opportunities offered by the qualified use of ICT, both from an information viewpoint and utilization of ICT in the working and technological operations in agriculture. Most likely, this is due to the long-lasting lack of resources which commenced during the transition process and is slowly improving after EU accession.

\section{The Impact of EU Accession on the Changes in Agribusinessmen's Managerial Work}

One of the research targets was to find an answer to the question regarding what kind of impact had EU membership had on the managerial activities of agribusinessmen. $90.63 \%$ of managers began with utilization of new approaches and techniques in their work. Only $9.38 \%$ of managers stated in their responses that there was no need to undertake any changes in connection with their managerial practices.

Our research has confirmed that if agricultural managers have the ambition to compete with other local farmers and those from other EU states, then they have to deal successfully with all the new direct and indirect challenges stemming from this membership.

The greatest challenge in almost all companies was the capacity to deal efficiently with unknown and robust administration. According to managers, following EU accession the level of bureaucracy significantly increased in comparison with the pre-accession period. Less complicated was mastering the work linked to information technologies (56.99\%), despite the fact that it is the second most substantial challenge. Other challenges are connected to the higher time demand related to managerial work, in other words, the hours spent in the office for agribusinessmen became longer (46.24\%). This is followed by increased stress (47.31\%). High significance is assigned to lobbying activities, which are necessitating essentially better skills than prior to EU accession. The positive trend is that owing to professionally more demanding managerial work, it is necessary to participate in various education activities (43.01\%). Managers also indicated that they began learning foreign languages (25.81\%). According to managers it is also important to be prepared for negotiations with inputs suppliers and agricultural production buyers (16.13\%). In addition, top managers have to face high pressure with regard to maintaining deadlines in their business activities (31.18\%).

$76.04 \%$ of managers claim that they introduced project management into their managerial work, arguing that through various projects they can obtain additional financial resources for key activities of their agricultural holdings, required e.g. for production modernization and diversification.

The results of our survey confirm that outsourcing has already penetrated the agricultural holdings. It is utilized by half of the surveyed companies (46.88\%). With regard to the target areas of outsourcing, accounting dominates with a share of $44.44 \%$. High on the list is also project formulation (37.78\%). Meaningful is also the share linked to animal feeding (31.11\%) and integrated pest management (31.11\%). With regard to the lowest share of outsourcing activities used by agricultural holdings services, logistics was indicated, only in $20 \%$ of cases.

\section{The Preferred Personality Characteristics Required for Successful Handling of Managerial Roles}

In recent period of turbulent development, managerial work is influenced among the other factors by globalization, information asymmetry,

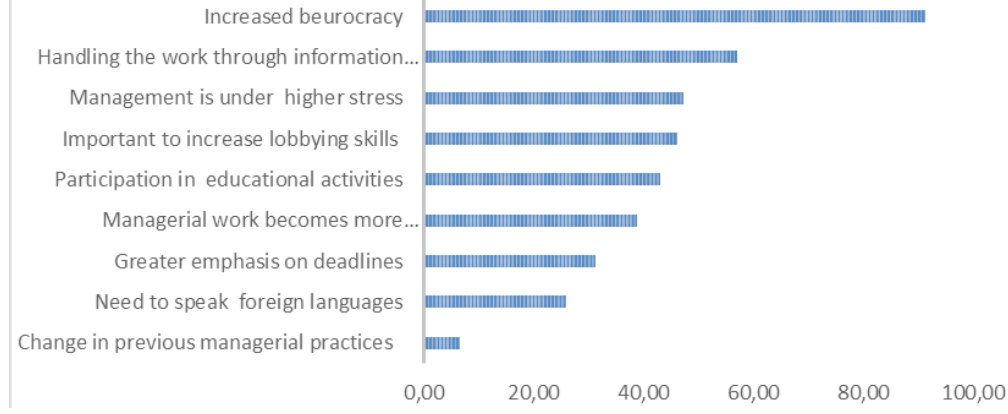

1: The Greatest Challenges for Agribusinessmen after EU Accession, in percentage Source: Own research 
need for permanent innovations, abundance of production capacities and knowledge management. Managers of agricultural holdings have to be properly prepared for all of this.

It is good that managers prefer positive personal suppositions. However, the underestimation of empathy is surprising (28.42\%), or assertiveness $(27.37 \%)$, though high emotional and social intelligence are according to managers important for communication. It is expected, that a competent manager, alongside knowledge intelligence (IQ), would have emotional and social intelligence. So it is about a significant shift in relation to personal suppositions and this, in its complexity, is valid also for agribusinessmen who have to be prepared in relation to this shift through participation in various training and educational activities, in order to be properly equipped for effective people management.

\section{DISCUSSION}

Every change, whether in the internal or external environment is forcing managers to search and utilize new methods and tools in order ensure the company's competitiveness and sustainable development. On the basis of the undertaken research we can state that the first scientific hypothesis was confirmed. New trends mean introduction of project management, extension services, the formation of supply - sale associations, introduction of a quality management system and the other new tools of management. In this regard our results are in line with Kádárová and Durkáčová (2012) and Karabašová (2010). A positive result is that the agricultural holdings use diversification as a tool for their sustainable development (92.71\%), as well as for production, economic and social functions' viability. This result is in line with the analogical survey undertaken by Tóthová and Fila (2014), when in the selected group of agricultural holdings more as 90\% utilized the diversification with the purpose to improve their competitiveness and financial situation. Furthermore, the input - output cooperatives/associations are not representing so far strong managerial tools of agricultural managers, however, the number of these models are increasing. In our selected group 48, 96\% of agricultural holdings are members in various types of cooperatives and associations. If we compare this result with those achieved by Sedik (2016), e.g. in Hungary or Ukraine, Slovakian achievement is much more favorable.

Scientific hypothesis no. 2 was also confirmed. This related to the dependency between changes in the external environment and their impact on the agricultural holdings. This hypothesis is analogical with the results of Ross and O'Connor (2012). Moreover, hypothesis no. 3 has been confirmed as well. This is linked to organizational and management structures, if they are well tailored, then they do have a positive impact on sustainable company development. This is in accordance with the statement made by Serenčéš and Tóth (2012).

Hypothesis no. 4 referring to the high importance of managerial functions acknowledged by managers, was not directly confirmed by the Friedman test. Managers of the surveyed group consider as the most important functions organizing, decision - making process, and the shortterm plans as the most important. This is obviously the result of a pragmatic approach to give preference to those tasks which are more pressing, because of production or administrative problems which are evoking direct pressure on managers. The same result was achieved by Filo (2013).

The next hypothesis was about the impact of EU accession on the agricultural managers. The EU accession resulted in more positive than negative outcomes and this in a meaningful way influences the nature of an agricultural manager's work. From the responses of managers it emerges that in at least half of the cases, the company's management is implementing various measures preferably in the field of human resources, adjustments of organizational structures in favor of slimmer and more simple structures; they do invest in new technologies and machines, also they introduced different diversification programmes; and the companies became members of various commodity and production associations. This is in line with Fresco (2015) and Bělohlávek et al. (2006).

Managers are convinced that they have to improve their position on the market. According to them, it is important to continue alongside of the CAP with state support of the agricultural sector. In this connection, according to agro managers, it is necessary to elaborate a clearly defined long-term strategy and vision for Slovak agricultural primary production, the food processing sector, as well as for rural development.

\section{CONCLUSIONS}

The research of the submitted article stemmed out from the questionnaire survey composed from 40 questions, in frame of which have been addressed 96 managers of agricultural holdings. Mathematical and statistical methods have been used in order to evaluate the 5 research hypotheses.

The results of this research confirm that the face of agriculture is gradually changing. It is not anymore about the physical strengths of the farmers but more and more are utilized progressive innovations, such as organic farming, agro/ecological approaches, precision agriculture, ICT. Our results are in line with statement of Yar (2017). Among the most important challenges in the light of frequently reformed CAP is attempt to modernize sector and make it more market oriented. 
The most important challenges are to increase competiveness, the quality of the environment and countryside, life in rural areas and the diversification of rural economies. This everything has a significant impact on the agricultural managers which have to adjust their knowledge and skills to the new requirements. However, the managers do consider as the significant barrier for modernization of agriculture the high investment costs for progressive technologies. This result coincides with research of Takácsné et al. (2018).

The EU accession had an overall positive impact on the managerial work. $90.63 \%$ of managers began with utilization of new approaches and tools in their work. Managers in their business implemented from modern managerial tools outsourcing, project management, controlling, ICT, diversification, more flexible organizational structures, management quality systems, precision agriculture, organic farming, agro-ecological approaches, satellites etc. Dobošová et al. (2017) confirmed that controlling is becoming new significant tool for effective managerial decisions.

Our research also has confirmed that if agricultural managers have the ambition to compete with other local farmers and those from other EU states and they want to deal successfully with all the new direct and indirect challenges stemming from this membership. Research confirmed that the managerial performance is more complex. The emphasis is given to product quality and effective cost utilization, an important trend towards more effective production and economic results.

\section{Acknowledgement}

This article was created within the Vega project: Social Responsibility and Innovation Activities at Declining the Food Losses with focus on the Friendly Use of the Environment. Project Registration Number: 1/0802/18, 2018-2020.

\section{REFERENCES}

BELOHLÁVEK, F. et al. 2006. Management. 2nd Edition. Brno: Computer Press.

FILO, M. 2013. The Evaluation of the Strategic Management in the Selected Agricultural Companies of the Slovak Republic [in Slovak: Hodnotenie strategického riadenia vo vybranom súbore agropodnikov na Slovensku]. Diseertation Thesis. Nitra: Slovenská pol'nohospodárska univerzita. Fakulta ekonomiky a manažmentu.

DOBOŠOVÁ, L. et al. 2017. Controlling as a Managerial Tool in Agricultural Business. In: Competetivenness of European Agriculture and Food Sectors, Agrarian Perspectives, $26^{\text {th }}$ International Scientific Conference. September 2017. Praque, pp. 57-63.

FRESCO, L. 2015. Some thoughts about the future of food and agriculture. South African Journal of Science, 110(5/6): \#a0066.

KÁDÁROVÁ, J. and DURKÁČOVÁ, M. 2012. Analysis of utilization of the management tools applied in the process of increasing the company performance. In: Transferinovácií, 24: 37-41.

KARABAŠOVÁ, L. 2010. Methodological Procedure for Application of Balanced Scorecards into the Organization [in Slovak: Metodický postup pre aplikáciu Balanced Scorecard do organizácie]. [Online]. Available at: https:// docplayer.net/23968972-Metodicky-postup-pre-aplikaciu-balanced-scorecard-do-organizacie.html [Accessed: 2018, April 27].

MPRV SR, 2018. The Reports about Agriculture and Food Industry from 2001 to 2017 in Slovak Republic. [in Slovak: Správy o polnohospodárstve a potravinárstve v SR 2001-2017]. Ministry of Agriculture and rural development of the Slovak Republic. [Online]. Available at: http://www.mpsr.sk/index. php?navID=123\&id=12392 [Accessed: 2018, April 27].

ROOS, G. and O'CONNOR, A. (Eds.). 2015. The idea of integrating innovation: Entrepreneurship and a systems perspective. In: Integrating Innovation. University of Adelaide Press, pp. 3-32.

SEDIK, D. 2016. Agricultural Cooperatives in the Value Chain in Eurasia. In: The Agri-food Value Chain: Challenges for Natural Resources Management and Society. International Scientific Days 2016. May 2016. Faculty of Economics and Management, Nitra, Slovak Republic. Nitra: SUA.

SERENČÉŠ, P. And TÓTH, M. 2012. Evaluation of Creation and Distribution of Added Value in Slovak Agriculture. In.: Global Commodity Markets: New Challenges and the Role of Policy International Scientific Days 2012. Faculty of Economics and Management, Nitra, Slovak Republic. Nitra: SUA.

TAKÁCSNÉ, G. K. et al., 2018. Precision Agriculture in Hungary: Assessment of Perceptions and Accounting Records of FADN Arable Farms. Studies in Agricultural Economics, 120(1): 47-54.

TÓTHOVÁ, V. and FIL'A, M. 2014. The Evaluation of Agricultural Entities' Diversification in Context of Cultivated Land's Scale [in Slovak: Hodnotenie diverzifikácie pol'nohospodárskych subjektov v kontexte rozsahu obhospodarovanej pôdy]. Ekonomika polnohospodárstva, 14(3): 69-81.

YAR, L. 2017. Seven Innovations which Change an European Agriculture. Technologies and Innovations are the Basis for Sustainable Agriculture in the World. Euractiv. Available at: https://euractiv.sk/section/vedaa-inovacie/news/sedem-inovacii-ktore-menia-polnohospodarstvo-v-europe/ [Accessed: 2017, July 29]. 
Contact information

Zuzana Juríčková: zuzana.jurickova@uniag.sk

Zuzana Kapsdorferová: zuzana.kapsdorferova@uniag.sk

Mária Kadlečíková: maria.kadlecikova@uniag.sk 